\title{
Barriers to the Use of Serious Computer Games in the Practical Work with Children with Educational Difficulties
}

\author{
Margarita Stankova ${ }^{1}$, Daniela Tuparova ${ }^{2}$, Georgi Tuparov $^{3}$, Polina Mihova ${ }^{4}$ \\ ${ }^{1,4}$ Department of Health care and social work, NBU, Sofia, Bulgaria \\ ${ }^{2}$ Department of Informatics, South-West University "Neofit Rilski”, Blagoevgrad, Bulgaria \\ ${ }^{3}$ Department of Informatics, NBU, Sofia, Bulgaria
}

\begin{abstract}
This study looks into the barriers and factors that influence the use of educational computer games (ECGs) that speech and language therapists face in the treatment of children with special educational needs (SEN). 111 respondents were administered a 12question questionnaire in 2018/2019. The results showed that $87 \%$ of all the respondents used games. The highest percentage of users was from the 20-30 years old age group. The professionals with extensive working experience of 16-20 years and 21+ indicated the lack of time for games as a significant barrier. The study showed positive attitudes towards the use of ECGs in working with children with SEN and the need for developing high-quality games that match current practice of professionals.
\end{abstract} SLT.

Keywords - computer games, special education, SEN,

\section{Introduction}

Serious games combine pedagogical methods in order to display knowledge and skills and to teach, which makes them different from games that we use for entertainment only [1].

DOI: $10.18421 /$ TEM103-22

https://doi.org/10.18421/TEM103-22

Corresponding author: Margarita Stankova,

Department of Health care and social work, New Bulgarian University, Sofia, Bulgaria.

Email: mstankova@nbu.bg

Received: 12 April 2021.

Revised: 05 July 2021.

Accepted: 12 July 2021.

Published: 27 August 2021.

(cc) BY-NC-ND (C) 2021 Margarita Stankova et al; published by UIKTEN. This work is licensed under the Creative Commons Attribution-NonCommercial-NoDerivs 4.0 License.

The article is published with Open Access at www.temjournal.com
Educational computer games (ECGs) offer rich interactive environment and they can contribute to problem solving in various contexts. They let children use information from a variety of different sources [2]. Computer games give students the opportunity to study actively and develop flexibility, which allows them to practice their new skills in different situations. Computer games enhance the development of visual spatial behavior, thinking, motor skills, visual attention and hand-eye coordination, problem identifying and problem solving, social skills and self-monitoring [3]. The ECGs improve intellectual abilities, visual-spatial functions and concentration [4], short and long-term memory [5], learning and social interactions [6]. Games allow the child to try out different ways of studying, they improve thinking and logic [7] while enhancing resistance to frustration [8]. Games offer challenges along with entertainment. They also stimulate curiosity and improve cooperation [9]. They increase children's motivation and they can be used for cognitive assessment and cognitive training [10].

Initially serious computer games were used in the educational process mainly for rest, as a reward or motivation, helping the children to participate in educational activities, maintaining concentration, and keeping their attention. Over time games have been used to develop special skills, as some of the products are specific and recommended for children with learning difficulties. In terms of online teaching, games gain more importance, especially considering the fact that children with Special educational needs (SEN) often have serious trouble being active during online classes. At the same time, the traditional training for speech and language therapists implies working in a room and a combination of studying and completion of tasks one after another. The quick development of technology requires knowledge and computer skills that are different from the basic training of the professionals, which is probably one of the biggest obstacles to speech and language 
therapists in the use of technology in their work, albeit the fact that ECGs offer a number of benefits: to start with, the positive effect on the therapy process, children's grades and their ability to do additional work at home [11].

Using ECGs in special education allows the children to work and complete the tasks at their own pace and gives them better motivation to study [12]. Games can improve language, math and social skills, as well as the general knowledge of children with SEN [13]. Computer games can be used to improve facial-recognition abilities, especially in children with autism [14] and help children with developmental disorders to participate in occupational trainings, to master a professional role, and to prepare for a working environment [15]. Games can teach children with autism new skills [16] and make them less anxious and more confident [17]. Gamified learning increases the motivation and concentration [18] and resolves the behavioral problems of children with ADHD [19]. Games improve visual attention in children with learning disabilities [20], particularly if they are individualized and well-matched [21]. Computer games can improve reasoning abilities [22] and everyday living skills [23].

Games can improve the integration of children with SEN and make learning resources more accessible [24]. Under the conditions of social isolation and the demand for online tuition, it is interesting to discuss the problems professionals face while using serious games in their work with children. Current advances in technology allow for telepractices to be implemented for the benefit of the patient, the professionals or both. The search for information related to health on the Internet and the expectations for finding useful Internet sources are relatively high, however, many factors make the process difficult. Some of them are related to barriers to patients and professionals, others to increasingly sophisticated technology, legal and ethical considerations [25]. E-learning education would help children get a solution that meets their individual needs and combines an approach related to learning and cognitive skills to achieve maximum effect [26].

There is a number of barriers for using computer games in classrooms by teachers, namely, lack of flexibility in the school curriculum, the perceived negative effect of the games since students are not ready to learn through games, lack of supporting materials, fixed school schedules and limited budget, lack of correspondence between the content of the games and the educational programs, licenses and technical security, lack of knowledge how to use technology and lack of computer competence [27], high price, lack of good technological resources and high-quality games, skepticism of the colleagues, not having enough time, parents' feedback [28],[29]; social influence [30]. Limited resources and games' high prices, as well as the lack of clear financial aid for the best educational solutions pose an important issue [27], [28]. The weak correspondence of the games to the curriculum at schools is another serious holdback [31].

Computer games can be included in the work with children, but some teachers still remain skeptical about their use [32]. Some educational professionals believe that games can distract children [33]. They also point out the lack of previous experience in using games as one of the problems [34].

While barriers to the use of serious computer games by teachers have already been discussed extensively, their use by professionals who work with children with developmental disorders e.g., speech and language therapists, and the factors associated with that use are still unclear.

The application of the ECGs in the practice of speech therapists would probably differ from that of teachers, because speech therapists often work in individual setting with children with developmental disorders. Although the practical work with children with SEN can occur in the educational environment in schools and kindergarten, the main work of speech therapists is associated with the treatment of disorders not with the regular educational process. Therefore, the appropriately developed computer games that correspond to the therapeutic programs of the speech therapists can teach children new cognitive skills, including linguistic skills and is an essential step in aligning the work of speech therapists with modern life. The identification of the barriers might significantly contribute to the better practices in educational game development and may support the learning process.

\section{Materials and Methods}

The aim of the study was to investigate: (1) whether professionals with practice in the field of education use ECGs when working with children with SEN; (2) what types of games they use; (3) how they apply the games; (4) what their attitude to the effect of games on cognitive functions and behaviour of the children is and (5) what the barriers to using games are. The factors that were relevant to these barriers were also of interest.

The demographic data included in the survey were Gender and Age, where the participants were divided into five age groups - from 20 to 30 years, from 31 to 40 years, from 41 to 50 years, from 51 to 60 years and over 60 years. Another parameter of the demographic data was the profession of the respondents. The answers were chosen to match the professionals who actually work with children with developmental disorders. According to established 
practices, professionals who work with children with special educational needs in Bulgaria perform diagnostics and therapy in a multidisciplinary team and less often work individually through activities applied by a professional in private practices at parents' request. Other professionals - psychologists, primary teachers, and resource teachers often support children with developmental disorders [35]. The selected options were as follows: Speech Therapist, Audiologist, Special Educator, Psychologist, Linguist, Teacher, Educator, Medical doctor, other. For the purposes of this paper, only speech therapists were selected to present a clear picture of the situation related to the use of the ECGs in the assessment and therapy of children with SEN in speech therapy practice. The results would help to create practices that include educational games suitable for speech therapy work and better training of professionals for their use. Another parameter related to the demographic description of the participants was the practical experience in working with children with the SEN. The answers were divided into 6 groups: the smallest experience - 1-5 years, 6-10 years, 11-15 years, 16-20 years and the largest experience - over 21 years. We hypothesized that this factor would affect the data on the use of the ECGs by professionals, as it is related to the age of the participants and their ability to select appropriate materials for working with children with developmental disorders. In order to obtain a more homogeneous group of respondents, they were asked the question about the age of the children they work with, and the answers were ranked into five groups 0-3 years, 4-6 years, 7-11 years, 12 -15 years, 16+ years. Our expectation was that most of the participants work with children of different age groups and many of them work in more than one workplace according to the other data in the field. The answers regarding the workplace included the following possibilities: Hospital, Health Centre/Clinic, Kindergarten, School, and School for children with disabilities, Private practice.

The following instruction was addressed to the participants: "This survey aims to evaluate whether and how educational computer games are used in working with children with special educational needs. It is anonymous. Thank you in advance for your participation!"

The participation in the study was voluntary.

The survey included 26 questions. They were grouped into several groups: first group of questions - focused on whether educational computer games are used in diagnostics and therapy, for rest, or other purposes, what types of computer games are used, according to the access of the game and according to the type of game, e.g. games for learning language and reading, memory, attention, motor skills, mathematics, general knowledge, role-playing games, puzzles, games including social elements, sports simulation games, adventure games as well as according to the type of the game - individual or group and games for different number of participants. The second group of questions concerned the frequency of use of computer games - in diagnosis and assessment, for therapy and for rest when working with children with the SEN. The third group of questions concerned the device on which the games are used, the information about the games and the reasons for their use - for training in basic knowledge and skills, for training in additional knowledge and skills, for assessment of knowledge and skills and for fun. The fourth group of questions was related to the attitude of the professionals for the children's performance in games and if the games meet the specific educational goals. The fifth group of questions included the opinion of professionals on the impact of games on cognitive functions in various fields - general knowledge, social skills, creativity, decision making, development of ideas, motivation, thinking and communication and the way the parents accept the inclusion of games in the educational and therapy practice. The sixth group included an important issue related to the need of the professionals for additional training and issues directly targeted to the barriers to the use of the ECGs in working with children with the SEN. See [11], [34], [35] for details on the results of the other questions of the survey.

For the purposes of this paper, only some of the data obtained related to barriers was used and only participants with a qualification in speech and language therapy were included.

\section{Results}

The participation in the study was voluntary. The participants featured in the current analysis were 111 speech and language therapists. For the purposes of the current paper, the 12 questions related to the subgroup "Barriers" were extracted and the answers were analysed. Some of the barriers included were related to the expectations of negative learning outcomes, non-compliance with the school program, lack of equipment, strict school schedules [31], limited budgets, lack of support, children's skills [27]. Additionally, questions related to the skills of professionals to use technology were added, as we were interested in the factors influencing their readiness to use the ECGs in the assessment and therapy of children with the SEN.

The study was conducted during the academic 2018/2019 year.

The barriers identified were included in a subgroup of 12 questions to speech and language professionals. The possible answers were the following:

1. No time for games;

2. Cost of the game; 
3. There are no games that have serious educational and therapy effect;

4. There is no information where to find high quality games;

5. I am not tech savvy and I can't use technology;

6. It is difficult to find games that correspond to my therapy program;

7. I don't have the support of a computer specialist;

8. Children are not keen on working with technologies;

9. Children do not have knowledge and skills to work with technologies;

10. Parents think that the games are not useful for the children;

11. Parents think that the games are irrelevant to the therapy process;

12. I believe that the use of games devalues my work and makes it accessible to anyone who is not a professional.

These questions follow the Likert type answers with 1 to 5 points - 1 strongly disagree to 5 strongly agree.

Online software was used to compare the different groups - MedCalculator.

(https://www.medcalc.org/manual/comparison of proportions .php)

The Online software was chosen because of its accessibility and intuitive interface.

The comparison is based on the Chi Square Test for samples larger than 20 and the Fisher's Exact Test for smaller samples.

(https://www.medcalc.net/statisticaltests/fisher.php).

The notation $\chi^{2}(\mathrm{n})$ is used to indicate $\chi^{2}$ statistics with degree of freedom $n$.

Descriptive statistics were calculated using SPSS program.

Responses were received from 111 respondents, speech and language professionals working with children with SEN, and 27 (24\%) indicated that they did not use educational computer games (ECGs), while the remaining $84(76 \%)$ declared use of educational computer games (ECGs) in their practice. Only $3(2.7 \%)$ of the respondents were men. For that reason, data on the gender of the respondents was not analysed. For each of the subgroups "Age of the children you work with" and "Place of work" the sum of the percentages exceeded 100, because for some of the respondents more than one category was valid (Table 1.). The relative share of those working with children in the age group 7-11 years old was the highest. About $66 \%$ worked in school or kindergarten and $9.91 \%$ - in the health sector. One third of the respondents were in private practice.

The professionals who participated in the study are currently employed by the Speech Therapy Centres in Bulgaria. They mainly work in mainstream schools and kindergartens with children with learning difficulties, language disorders, autism, ADHD, mental retardation. A small number of the Speech and Language Therapists work in Health centres and hospitals.

The professionals in Speech Therapy Centres in Bulgaria have high qualification and work experience. On the other hand, some speech and language therapists working with children with special educational needs practice in schools and kindergartens and in the private sector too (see Table 1.).

Table 1. Demographic characteristics of the participants

\begin{tabular}{|c|c|c|}
\hline Age & $\mathrm{N}$ & $\%$ \\
\hline 20-30 & 12 & $10.81 \%$ \\
\hline $31-40$ & 33 & $29.73 \%$ \\
\hline $41-50$ & 48 & $43.24 \%$ \\
\hline $51-60$ & 12 & $10.81 \%$ \\
\hline $60+$ & 6 & $5.41 \%$ \\
\hline \multicolumn{3}{|l|}{ Work experience } \\
\hline $1-5$ & 19 & $17.12 \%$ \\
\hline $6-10$ & 19 & $17.12 \%$ \\
\hline $11-15$ & 27 & $24.32 \%$ \\
\hline $16-20$ & 27 & $24.32 \%$ \\
\hline $21+$ & 19 & $17.12 \%$ \\
\hline \multicolumn{3}{|l|}{ Age of the children you work with } \\
\hline $0-3$ years & 33 & $29.73 \%$ \\
\hline 4-6 years & 91 & $81.98 \%$ \\
\hline $7-11$ years & 102 & $91.89 \%$ \\
\hline $12-15$ years & 79 & $71.17 \%$ \\
\hline $16+$ years & 28 & $25.23 \%$ \\
\hline \multicolumn{3}{|l|}{ Place of work } \\
\hline Hospital & 7 & $6.31 \%$ \\
\hline Health center/clinic & 4 & $3.60 \%$ \\
\hline Kindergarten & 25 & $22.52 \%$ \\
\hline School & 48 & $43.24 \%$ \\
\hline $\begin{array}{l}\text { School for children with dis- } \\
\text { abilities }\end{array}$ & 4 & $3.60 \%$ \\
\hline Private practice & 40 & $36.04 \%$ \\
\hline
\end{tabular}

The answers at the "Place of work" column correspond to the "Age of the children you work with" column - some of the professionals' work with children from different age groups. We expected that the data collected for our sample could present a reliable picture of the use of the ECGs in the work of speech therapists, as employees of Speech Therapy Centres are highly qualified and experienced. They would be more interested in the application of new technologies in speech and language therapy and assessment and they would participate in trainings and additional qualifications to work with them. In addition, these professionals often work in a team with teachers in schools and kindergartens to build up individual programs for working with children with developmental disorders and the current study will disclose additional information about the barriers 
to teams working in the diagnosis and treatment of developmental disorders.

The reliability of the group of questions "Barriers" was determined by the Cronbach's alpha coefficient. The questions from the subgroup "Barriers" were 12. The Cronbach's alpha for the questions in the subgroup "Barriers" was 0.818 with 111 answers to all the questions.

The number of the speech and language professionals who use and do not use the ECGs in their practice according to their age is presented in Table 2 .

Table 2. ECGs' users distributed by the age of the participants

\begin{tabular}{|l|l|l|c|}
\hline Age & $\begin{array}{c}\text { Overall } \\
\text { Number }\end{array}$ & $\begin{array}{c}\text { ECG } \\
\text { Users N }\end{array}$ & $\%$ \\
\hline $\mathbf{2 0 - 3 0}$ & 12 & 10 & $83.33 \%$ \\
\hline $\mathbf{3 1 - 4 0}$ & 33 & 26 & $78.79 \%$ \\
\hline $\mathbf{4 1 - 5 0}$ & 48 & 38 & $79.17 \%$ \\
\hline $\mathbf{5 1 - 6 0}$ & 12 & 6 & $50.00 \%$ \\
\hline $\mathbf{6 0 +}$ & 6 & 4 & $66.67 \%$ \\
\hline Total & $\mathbf{1 1 1}$ & $\mathbf{8 4}$ & $\mathbf{7 5 . 6 8 \%}$ \\
\hline
\end{tabular}

The overall percentage of speech and language professionals who used the ECGs in their practice was high. As expected, the highest percentage of the ECGs users was within the age group of 20-30, but the percentage of professionals who used games was also high in the age groups of $31-40$ and $41-50$ years old.

The number of those who use and do not use the ECGs in terms of the duration of their work experience is presented in Table 3 .

Table 3. ECGs users distributed by the length of work experience

\begin{tabular}{|l|l|l|l|}
\hline \multicolumn{1}{|c|}{$\begin{array}{c}\text { Work } \\
\text { Experience }\end{array}$} & $\begin{array}{c}\text { Overall } \\
\text { Number }\end{array}$ & $\begin{array}{c}\text { ECG } \\
\text { Users N }\end{array}$ & $\%$ \\
\hline $\mathbf{1 - 5}$ & 19 & 18 & $95 \%$ \\
\hline $\mathbf{6 - 1 0}$ & 19 & 15 & $79 \%$ \\
\hline $\mathbf{1 1 - 1 5}$ & 27 & 20 & $74 \%$ \\
\hline $\mathbf{1 6 - 2 0}$ & 27 & 21 & $78 \%$ \\
\hline $\mathbf{2 1 +}$ & 19 & 10 & $53 \%$ \\
\hline Total & 111 & 84 & $76 \%$ \\
\hline
\end{tabular}

The length of the work experience is important for the use of the ECGs. There were statistically significant differences in the distribution of age intervals in both groups - Professionals Using ECGs and Professionals who do not use ECGs. Chi Square Test for independent samples was applied. Since there were 3 cells in which the expected values were less than 5, a combination of the first two intervals was made - 1 to 5 years and 6 to 10 years work experience. In this case, the expected values less than 5 were less than $20 \%$ and Chi Square Test for independent samples could be applied. The result was: $\chi^{2}(3)=8.16 ; \mathrm{p}=0.042$. There was a statistically significant difference between both groups - users and nonusers.

In addition, $87 \%$ (33) of the participants in the 110 years of work experience group used the ECGs in their practice and $13 \%$ (5) did not. The participants in the $21+$ work experience group were: users 53\% (10) and non-users $47 \%$ (9). The difference in age groups was statistically significant (Fisher's exact test: $\mathrm{p}=$ 0.008). When comparing the other groups 1-10 vs $11-15,1-10$ vs $16-20,16-20$ vs $21+$ in terms of duration of work experience no significant differences were found.

\section{Barriers to the use of the ECGs in the work with children with Special Educational Needs}

The descriptive statistics of the distributions of the answers to the questions from the subgroup related to barriers are presented in Table 4 . The three most serious barriers with the highest average of the answers were the following: "Cost of the game"; "There are no games that have serious educational and therapy effect" and "There is no information where to find high quality games".

Table 4. Barriers to the use of ECGs in the work with children with SEN - means, medians and SD

\begin{tabular}{|c|c|c|c|c|}
\hline Barrier & $\begin{array}{l}\text { Age } \\
\text { group }\end{array}$ & Median & Mean & SD \\
\hline \multirow{5}{*}{$\begin{array}{l}\text { There are no } \\
\text { games that have } \\
\text { serious educational } \\
\text { and therapy effect }\end{array}$} & $20-30$ & 3.50 & 2.83 & 1.34 \\
\hline & $31-40$ & 4 & 3.36 & 1.14 \\
\hline & $41-50$ & 4 & 3.73 & 1.40 \\
\hline & $51-60$ & 4.50 & 4.17 & 1.19 \\
\hline & $60+$ & 3 & 3.33 & 0.82 \\
\hline
\end{tabular}

The item "It is difficult to find games that correspond to my therapy program" had also a high score. Finding good ECGs was associated not only with the effects they would have on the therapy outcome, but also with the specific disorder and the developmental level of the child. Items "Children are not keen on working with technologies" and "Children do not have knowledge and skills to work with technologies" had the lowest value.

The professionals working with children with SEN obviously needed more information about the ECGs and the availability of games suitable for working with children with developmental disorders. Surprisingly, the professionals do not consider that parents would accept the use of games as a useless therapy approach.

The non-parametric Man-Whitney U test was used for comparison of the two independent samples users and nonusers due to the ordinality of the data in the Likert type of answers. The results for the barriers that showed statistically significant differences between both groups are presented in Table 5 . 
Table 5. Barriers to the use of ECGs in the work with children with SEN - users and nonusers

\begin{tabular}{|l|l|l|l|l|l|}
\hline $\begin{array}{l}\text { Barriers } \\
\text { (5- definitely Yes, } \\
\text { 1-definitely No) }\end{array}$ & $\begin{array}{l}\text { Users } \\
\text { mean }\end{array}$ & $\begin{array}{l}\text { Users } \\
\text { median }\end{array}$ & $\begin{array}{l}\text { Nonusers } \\
\text { mean }\end{array}$ & $\begin{array}{l}\text { Nonusers } \\
\text { median }\end{array}$ & $\mathbf{p}$ \\
\hline $\begin{array}{l}\text { There are no games that } \\
\text { have serious educational and } \\
\text { therapy effect }\end{array}$ & 3.37 & 4.00 & 4.11 & 4.00 & 0.008 \\
\hline $\begin{array}{l}\text { There is no information } \\
\text { where to find high quality }\end{array}$ & 3.40 & 3.50 & 4.07 & 4.00 & 0.019 \\
\hline \begin{tabular}{l} 
games \\
\hline I am not tech savvy and I \\
can't use technology
\end{tabular} & 1.99 & 1.50 & 2.31 & 3.00 & 0.003 \\
\hline $\begin{array}{l}\text { It is difficult to find games that } \\
\text { correspond to my therapy } \\
\text { program }\end{array}$ & 3.19 & 3.00 & 4.11 & 4.00 & 0.002 \\
\hline $\begin{array}{l}\text { I don't have the support of a } \\
\text { computer specialist }\end{array}$ & 2.69 & 3.00 & 3.59 & 4.00 & 0.006 \\
\hline $\begin{array}{l}\text { I believe that the use of } \\
\text { games devalues my work } \\
\text { and makes it accessible to } \\
\text { anyone who is not a profes- }\end{array}$ & 2.13 & 2.00 & 2.81 & 3.00 & 0.013 \\
\hline \begin{tabular}{l} 
sional \\
\hline
\end{tabular} & & & & \\
\hline
\end{tabular}

There was no significant difference between both groups - users and nonusers of ECGs for the following barriers: "No time for games", "Cost of the game", "Children are not keen on working with technologies", "Children do not have knowledge and skills to work with technologies", "Parents think that the games are not useful for the children", "Parents think that the games are irrelevant to the therapy process". The barriers related to parents and children were perceived in the same way by professionals who use and do not use technologies.

With regard to the age groups, there was a significant difference in the distributions of the variables: "There are no games that have serious educational and therapy effect" $\left(\chi^{2}(4)=10.59 \mathrm{p}=\right.$ .03); "I am not tech savvy and I can't use technology" $(\chi 2(4)=11.55 \mathrm{p}=.021)$; "I don't have the support of a computer specialist" $(\chi 2(4)=12,56$ $\mathrm{p}=.014)$. The nonparametric Kruskal-Wallis Test was applied to compare independent samples with null hypothesis H0: The distributions of the variables were the same and the level of significance was 0.05 . "There are no games that have serious educational and therapy effect" was a serious barrier for the age groups 31-40, 41-50, 51-60 and it was not so important barrier for the age group 20-30 (Table 6.). Probably this age group had less experience working with children with the SEN. In the $60+$ group, the lower use of games in general is likely to have an impact on the result.
Table 6. Mean, median and SD for the barrier "There are no games that have serious educational and therapy effect" according to the age groups

\begin{tabular}{|l|l|l|l|}
\hline $\begin{array}{l}\text { Barrier } \\
\text { (5- definitely Yes, 1- definitely No) } \\
\mathbf{n}=111\end{array}$ & Mean & Median & SD \\
\hline No time for games & 3.23 & 3.00 & 1.32 \\
\hline $\begin{array}{l}\text { Cost of the game } \\
\text { There are no games that have serious } \\
\text { educational and therapy effect }\end{array}$ & 3.73 & 4.00 & 1.19 \\
\hline $\begin{array}{l}\text { There is no information where to find } \\
\text { high quality games }\end{array}$ & 3.57 & 4.00 & 1.30 \\
\hline $\begin{array}{l}\text { I am not tech savvy and I can't use } \\
\text { technology }\end{array}$ & 2.20 & 2.00 & 1.33 \\
\hline $\begin{array}{l}\text { It is difficult to find games that corre- } \\
\text { spond to my therapy program }\end{array}$ & 3.41 & 3.00 & 1.41 \\
\hline $\begin{array}{l}\text { I don't have the support of a computer } \\
\text { specialist }\end{array}$ & 2.91 & 3.00 & 1.46 \\
\hline $\begin{array}{l}\text { Children are not keen on working with } \\
\text { technologies }\end{array}$ & 1.80 & 1.00 & 1.02 \\
\hline $\begin{array}{l}\text { Children do not have knowledge and } \\
\text { skills to work with technologies }\end{array}$ & 2.07 & 2.00 & 1.17 \\
\hline $\begin{array}{l}\text { Parents think that the games are not } \\
\text { useful for the children }\end{array}$ & 2.68 & 3.00 & 1.19 \\
\hline $\begin{array}{l}\text { Parents think that the games are irrel- } \\
\text { evant to the therapy process } \\
\text { I believe that the use of games deval- } \\
\text { ues my work and makes it accessible }\end{array}$ & 2.55 & 3.00 & 1.23 \\
\hline
\end{tabular}

Not being tech savvy and lack of knowledge how to use technologies was not a serious barrier for the age groups $20-30,31-40$ and $41-50$, but for the age groups 51-60 and $60+$ the unfamiliarity with the technologies had a higher rate (Table 7.). The presumed reason for the differences is that younger people have more experience with IT and find it easier to cope with new technologies. They probably have more access to training too.

Table 7. Mean, median and SD for the barrier "I am not tech savvy and I can't use technology" according to the age groups

\begin{tabular}{|l|l|l|l|l|}
\hline Barrier & Age & Median & Mean & SD \\
\hline I am not tech & $20-30$ & 1 & 1.75 & 1.06 \\
\hline savvy and I & $31-40$ & 2 & 2.03 & 1.21 \\
\hline \multirow{2}{*}{$\begin{array}{l}\text { can't use } \\
\text { technology }\end{array}$} & $41-50$ & 2 & 2.06 & 1.17 \\
\cline { 2 - 5 } & $51-60$ & 3 & 3.25 & 1.42 \\
\cline { 2 - 5 } & $60+$ & 3 & 3.00 & 1.27 \\
\hline
\end{tabular}

"I don't have the support of a computer specialist" was a serious barrier for the age groups of 51-60 and $60+$. The age group 31-40 did not report that barrier as an important issue - Table 8 . 
Table 8. Mean, median and SD for the barrier "I don't have the support of a computer specialist" according to the age groups

\begin{tabular}{|l|l|l|l|l|}
\hline Barrier & Age & Median & Mean & SD \\
\hline $\begin{array}{l}\text { I don't have } \\
\text { the support of }\end{array}$ & $20-30$ & 3 & 2.92 & 1.56 \\
\hline $\begin{array}{l}\text { a computer } \\
\text { specialist }\end{array}$ & $\begin{array}{l}41-40 \\
\text { r }\end{array}$ & 2 & 2.73 & 1.38 \\
\hline & $51-60$ & 4.50 & 4.17 & 1.12 \\
\hline & $60+$ & 4 & 3.67 & 1.63 \\
\hline
\end{tabular}

Regarding the practical experience of working with children with special educational needs, there were statistically significant differences for the variables: "No time for games" $(\chi 2(4)=9,93 \mathrm{p}=, 042)$; "Cost of the game" $(\chi 2(4)=11,86 \mathrm{p}=, 018)$; "I am not tech savvy and I can't use technology" $(\chi 2$ (4) = $12,81 \mathrm{p}=, 012)$; "Parents think that the games are not useful for the children" ( $\chi 2(4)=13,33 \mathrm{p}=, 010)$. The lack of time was indicated as a significant barrier by specialists with extensive experience: 16-20 and $21+$. The probable reason for this is the availability of additional commitments of people who had many years of experience (Table 9.).

Table 9. Mean, median and SD for the barrier "No time for games" according to the length of work experience

\begin{tabular}{|l|l|l|l|l|}
\hline Barrier & $\begin{array}{l}\text { Years of } \\
\text { experience }\end{array}$ & Median & Mean & SD \\
\hline No time for & $1-5$ & 3 & 3.21 & 1.44 \\
\hline \multirow{2}{*}{ games } & $6-10$ & 3 & 2.42 & 1.17 \\
\hline & $11-15$ & 3 & 3.33 & 1.11 \\
\hline & $16-20$ & 4 & 3.44 & 1.45 \\
\hline & $21+$ & 4 & 3.63 & 1.21 \\
\hline
\end{tabular}

The results for the answers regarding the barrier "Cost of the game" was uneven, the most serious difficulty regarding the prices of the games was experienced by the professionals with 16-20 years work experience (Table 10.). We assume that it was harder for highly experienced professionals who still actively work with children with the SEN to find motivation to introduce new methods of work and to invest in training to work with them. The most experienced professionals are probably the least interested in new training.

Table 10. Mean, median and SD for the barrier "Cost of the game" according to the length of working experience

\begin{tabular}{|l|l|l|l|l|}
\hline Barrier & $\begin{array}{l}\text { Years of } \\
\text { experience }\end{array}$ & Median & Mean & SD \\
\hline Cost of the & $1-5$ & 4 & 4.05 & 1.13 \\
\hline game & $6-10$ & 4 & 3.58 & 1.39 \\
\hline & $11-15$ & 3 & 3.56 & 0.85 \\
\hline & $16-20$ & 5 & 4.15 & 1.23 \\
\hline & $21+$ & 3 & 3.21 & 1.23 \\
\hline
\end{tabular}

Not knowing the technologies was the most serious barrier for people with $21+$ work experience (Table 11.). This corresponds to the data that represented the age of the respondents and the barriers to the ECG use.

Table 11. Mean, median and SD for the barrier "I am not tech savvy and I can't use technology" ac-cording to the length of working experience

\begin{tabular}{|l|l|l|l|l|}
\hline Barrier & $\begin{array}{l}\text { Years of } \\
\text { experience }\end{array}$ & Median & Mean & SD \\
\hline $\begin{array}{l}\text { I am not } \\
\text { tech savvy }\end{array}$ & $1-5$ & 1 & 2 & 1.29 \\
\hline $\begin{array}{l}\text { and I can't } \\
\text { use tech- }\end{array}$ & $11-10$ & 1 & 1.63 & 0.96 \\
\hline \begin{tabular}{l} 
nology; \\
\hline
\end{tabular} & $21+$ & 2 & 2.37 & 1.15 \\
\hline
\end{tabular}

The distribution of the answers regarding the work experience for the barrier "Parents think that the games are not useful for the children" was relatively the same, except for the group of 6-10, where the answers were close to "No" and "Definitely not" (Table 12.).

Table 12. Mean, median and SD for the barrier "Parents think that the games are not useful for the children" according to the length of work experience

\begin{tabular}{|c|c|c|c|c|}
\hline Barrier & $\begin{array}{l}\text { Years of } \\
\text { experience }\end{array}$ & Median & Mean & SD \\
\hline \multirow{5}{*}{$\begin{array}{l}\text { Parents } \\
\text { think that } \\
\text { the games } \\
\text { are not use- } \\
\text { ful for the } \\
\text { children }\end{array}$} & $1-5$ & 3 & 3.16 & 1.34 \\
\hline & $6-10$ & 1 & 1.84 & 1.12 \\
\hline & $11-15$ & 3 & 2.81 & 1.08 \\
\hline & $16-20$ & 3 & 2.70 & 1.07 \\
\hline & $21+$ & 3 & 2.84 & 1.12 \\
\hline
\end{tabular}

SLTs usually work individually and parents' expectations are often high in terms of rapid therapy effect. In this case, however, the professionals do not think that parents would underestimate the work if they use technologies, which shows a good prospect for their application in the future development of more specialized and focused programs for children with special educational needs.

\section{Discussions}

The smaller practical experience was positively related to the wider use of the ECGs, which is probably again due to the age of the respondents.

For both groups of professionals - users and nonusers, the most common barrier to the inclusion of technologies was the high costs of the games, followed by the lack of games that are professionally designed and have an effect on training or therapy of children with special educational needs and the lack of information about available technologies. Professionals generally did not think that children 
would not like technologies or cannot use them. Professionals who did not use games to a greater extent believed that there are not enough games that give a therapy effect and correspond to the educational program. They also, unlike professionals who used the ECG, reported lack of skills to use technologies.

The differences in the barriers reported according to the age groups were found in the lack of games with a serious educational effect. This barrier turned out to be irrelevant for younger professionals and it was more typical for older ones, which is probably attributed to the length of experience of older professionals and high expectations regarding the selection of materials for working with children with developmental disorders. The expected differences in the perception of the barriers related to knowledge about the technologies and skills needed for their use corresponded to the age of the professionals. The same goes for the barrier related to the need for additional help by a computer specialist. The barrier related to the lack of time was an important issue for the professionals who had higher working experience.

\section{Conclusion}

A lot of flexibility is required from the education system nowadays to meet the challenges related to the work with children with developmental disorders, especially in case of distance and online learning. There is a greater need to include technologies and additional tools that motivate children, attract their attention and keep them on track. The use of technologies in the education of children with special educational needs is critical not only because of the difficulties in working with children themselves, but also because of the need for constant update of the knowledge and skills of the professionals. Every day they upgrade what they have already mastered and apply new specific tools, according to the needs of the child.

On the other hand, the lack of technologies, including the ECGs, which coexist well with the educational goals of the professionals and therapy aims and also correspond to the cognitive needs of children with special educational needs, accounts for the scepticism of professionals and further complicates their application. The development of technologies, which can help children with developmental problems, requires the collaboration of professionals in many areas. It requires combining and taking into account the capabilities of technology, diagnostic and therapeutical goals, the specific needs of children and the subjective preferences of the patients and their parents in regard to design, content, entertainment and fun opportunities.

\section{Acknowledgements}

This study was supported by a grant from the Bulgarian National Scientific Fund - Contract N DN-05/10, 2016, "Pedagogical and Technological Issues of Educational Computer Games" and the New Bulgarian University.

\section{References}

[1]. Zyda, M. (2005). From visual simulation to virtual reality to games. Computer, 38(9), 25-32. doi: 10.1109/MC.2005.297.

[2]. An, Y. J., \& Bonk, C. J. (2009). Designing digital game-based learning environments. TechTrends: Linking Research and Practice to Improve Learning, 53(3), 43-8.

[3]. Mitchell, A., \& Savill-Smith, C. (2004). The use of computer and video games for learning. A review of the literature. Learning and Skills Development Agency, London.

[4]. Wastiau, P., Kearney, C., \& Van den Berghe, W. (2009). How are digital games used in schools. European Schoolnet.

[5]. Rieber, L. P. (1996). Seriously considering play: Designing interactive learning environments based on the blending of microworlds, simulations, and games. Educational technology research and development, 44(2), 43-58. https://doi.org/10.1007/BF02300540

[6]. Kokkalia, G., Drigas, A., \& Economou, A. (2016). The Role of Games in Special Preschool Education. International Journal of Emerging Technologies in Learning (iJET), 11(12), 30-35.

[7]. Bottino, R. M., Ott, M., \& Tavella, M. (2014). Serious gaming at school: Reflections on students' performance, engagement and motivation. International Journal of Game-Based Learning (IJGBL), 4(1), 21-36.

[8]. Gee, J. P. (2003). What video games have to teach us about learning and literacy. Computers in Entertainment (CIE), 1(1), 20-20.

[9]. Razak, A. A., Connolly, T., \& Hainey, T. (2012). Teachers' views on the approach of digital gamesbased learning within the curriculum for excellence. International Journal of Game-Based Learning (IJGBL), 2(1), 33-51.

[10]. Lumsden, J., Edwards, E. A., Lawrence, N. S., Coyle, D., \& Munafò, M. R. (2016). Gamification of cognitive assessment and cognitive training: a systematic review of applications and efficacy. JMIR serious games, 4(2), e5888.

[11]. Tuparova, D., Veleva, V., \& Tuparov, G. (2019, May). About some barriers in usage of educational computer games by teachers in STEM. In 2019 42nd International Convention on Information and Communication Technology, Electronics and Microelectronics (MIPRO) (pp. 727-730). IEEE. 
[12]. Saridaki, M., Gouscos, D., \& Meimaris, M. (2010, October). Digital games-based instructional design for students with special education needs: Practical findings and lessons learnt. In Proceedings of the 4th European Conference on Games-Based Learning: ECGBL2010 (p. 343). Academic Conferences Limited.

[13]. Fernández-López, Á., Rodríguez-Fórtiz, M. J., Rodríguez-Almendros, M. L., \& Martínez-Segura, M. J. (2013). Mobile learning technology based on iOS devices to support students with special education needs. Computers \& Education, 61, 77-90.

[14]. Tanaka, J. W., Wolf, J. M., Klaiman, C., Koenig, K., Cockburn, J., Herlihy, L., ... \& Schultz, R. T. (2010). Using computerized games to teach face recognition skills to children with autism spectrum disorder: the Let's Face It! program. Journal of Child Psychology and Psychiatry, 51(8), 944-952.

https://doi.org/10.1111/j.1469-7610.2010.02258.x

[15]. Shaffer, D. W. (2007). Epistemic games as career preparatory experiences for students with disabilities. Journal of Special Education Technology, 22(3), 57-69.

[16]. Grossard, C., Grynspan, O., Serret, S., Jouen, A. L., Bailly, K., \& Cohen, D. (2017). Serious games to teach social interactions and emotions to individuals with autism spectrum disorders (ASD). Computers \& Education, 113, 195-211. https://doi.org/10.1016/j.compedu.2017.05.002

[17]. Chen, J., Wang, G., Zhang, K., Wang, G., \& Liu, L. (2019). A pilot study on evaluating children with autism spectrum disorder using computer games. Computers in Human Behavior, 90, 204-214. https://doi.org/10.1016/j.chb.2018.08.057

[18]. Sitra, O., Katsigiannakis, V., Karagiannidis, C., \& Mavropoulou, S. (2017). The effect of badges on the engagement of students with special educational needs: A case study. Education and Information Technologies, 22(6), 3037-3046. https://doi.org/10.1007/s10639-016-9550-5

[19]. Bul, K. C., Doove, L. L., Franken, I. H., Oord, S. V. D., Kato, P. M., \& Maras, A. (2018). A serious game for children with Attention Deficit Hyperactivity Disorder: Who benefits the most?. PloS one, 13(3), e0193681. https://doi.org/10.1371/journal.pone.0193681

[20]. García-Redondo, P., García, T., Areces, D., Núñez, J. C., \& Rodríguez, C. (2019). Serious games and their effect improving attention in students with learning disabilities. International journal of environmental research and public health, 16(14), 2480. https://doi.org/10.3390/ijerph16142480

[21]. Perelmutter, B., McGregor, K. K., \& Gordon, K. R. (2017). Assistive technology interventions for adolescents and adults with learning disabilities: An evidence-based systematic review and metaanalysis. Computers \& education, 114, 139-163. https://doi.org/10.1016/j.compedu.2017.06.005

[22]. Bakker, M., van den Heuvel-Panhuizen, M., \& Robitzsch, A. (2016). Effects of mathematics computer games on special education students' multiplicative reasoning ability. British Journal of Educational Technology, 47(4), 633-648.
[23]. Terras, M. M., Boyle, E. A., Ramsay, J., \& Jarrett, D. (2018). The opportunities and challenges of serious games for people with an intellectual disability. British Journal of Educational Technology, 49(4), 690-700. https://doi.org/10.1111/bjet.12638

[24]. Jaramillo-Alcázar, A., Cortez-Silva, P., GalarzaCastillo, M., \& Luján-Mora, S. (2020). A Method to Develop Accessible Online Serious Games for People with Disabilities: A Case Study. Sustainability, 12(22), 9584.

[25]. Stankova, M., Todorova, E., \& Ivanova, V. (2018). "Effects of the Application of Educational Computer Games in Work With Children with Special Educational Needs", Proc. of the National Conference on "Education and Research in the Information Society", pp. 94-98

[26]. Cinquin, P. A., Guitton, P., \& Sauzéon, H. (2019). Online e-learning and cognitive disabilities: A systematic review. Computers \& Education, 130, 152167. https://doi.org/10.1016/j.compedu.2018.12.004

[27]. Baek, Y. K. (2008). What hinders teachers in using computer and video games in the classroom? Exploring factors inhibiting the uptake of computer and video games. CyberPsychology \& Behavior, 11(6), 665-671.

[28]. Koh, E., Kin, Y. G., Wadhwa, B., \& Lim, J. (2012). Teacher perceptions of games in Singapore schools. Simulation \& Gaming, 43(1), 51-66. https://doi.org/10.1177/1046878111401839

[29]. Gerber, H. R., \& Price, D. P. (2013). Fighting baddies and collecting bananas: Teachers' perceptions of games-based literacy learning. Educational Media International, 50(1), 51-62.

[30]. Bourgonjon, J., De Grove, F., De Smet, C., Van Looy, J., Soetaert, R., \& Valcke, M. (2013). Acceptance of game-based learning by secondary school teachers. Computers \& education, 67, 21-35.

[31]. Rice, J. W. (2007). New media resistance: Barriers to implementation of computer video games in the classroom. Journal of Educational Multimedia and Hypermedia, 16(3), 249-261.

[32]. Gaudelli, W., \& Taylor, A. (2011). Modding the global classroom? Serious video games and teacher reflection. Contemporary Issues in Technology and Teacher Education, 11(1), 70-91.

[33]. Pastore, R. S., \& Falvo, D. A. (2010). Video Games in the Classroom: Pre-and in-service teachers' perceptions of games in the K-12 classroom. International Journal of Instructional Technology and Distance Learning, 7(12), 49-57.

[34]. Watson, W. R., Mong, C. J., \& Harris, C. A. (2011). A case study of the in-class use of a video game for teaching high school history. Computers \& Education, 56(2), 466-474. https://doi.org/10.1016/j.compedu.2010.09.007

[35]. Law, J., McKean, C., Murphy, C. A., \& Thordardottir, E. (Eds.). (2019). Managing children with developmental language disorder: Theory and practice across Europe and beyond. Routledge. https://doi.org/10.4324/9780429455308 